\title{
Majewskaea gen. nov. (Bacillariophyta), a new marine benthic diatom genus from the Adriatic Sea
}

\author{
Bart VAN De VIJVER ${ }^{1,2}$, Käthe RoberT $^{1,2}$, Andrzej WitKowski ${ }^{3} \&$ Suncica BosaK $^{4}$
}

\author{
${ }^{1}$ Meise Botanic Garden, Research Department, Nieuwelaan 38, 1860 Meise, Belgium; *corresponding author: \\ bart.vandevijver@plantentuinmeise.be \\ ${ }^{2}$ University of Antwerp, Department of Biology - ECOBE, Universiteitsplein 1, 2610 Wilrijk, Belgium \\ ${ }^{3}$ Institute of Marine and Environmental Sciences, University of Szczecin, 70-383 Szczecin, Poland \\ ${ }^{4}$ Department of Biology, Faculty of Science, University of Zagreb, Rooseveltov trg 6, 10000 Zagreb, Croatia
}

\begin{abstract}
During a survey of the diatom flora attached to carapaces of loggerhead sea turtles (Caretta caretta) from the Adriatic Sea, a large population of an unknown marine achnanthoid species was observed that could not be assigned to any of the currently described monoraphid diatom genera. Detailed morphological analysis based on scanning electron microscopy observations and comparison with a large number of monoraphid genera such as Madinithidium, Scalariella, Kolbesia and Karayevia, resulted in the description of the new benthic marine genus Majewskaea gen. nov. with the newly described Majewskaea istriaca sp. nov. as generitype. The new genus is characterized by a sternum valve showing a clear recurving ridge surrounding the entire valve margin, the presence of macroareolae closed internally by perforated hymenes, separated by a longitudinal hyaline area, a well-developed sternum and vestigial raphe slits. The raphe valve has a simple straight raphe with bent terminal fissures, a very fine striation pattern composed of macroareolae cut in two by a longitudinal hyaline zone, and a very shallow mantle. The new genus is illustrated using both LM and SEM observations and compared with other resembling marine and brackish Planothidium monoraphid species.
\end{abstract}

Key words: Adriatic Sea, marine diatoms, Majewskaea, sea turtles, new genus

\section{INTRODUCTION}

The past five years, the taxonomy of turtle-associated diatom taxa gained an increased interest that resulted in the description of several new species and even several new genera. In 2015, two new genera, Chelonicola Majewska et al. and Poulinea Majewska et al. were described from the carapace of olive ridley sea turtles (MAJEwSKa et al. 2015) followed by a third genus, Medlinella Frankovich et al., which was found on the skin of loggerhead sea turtles (Frankovich et al. 2016) in Florida. Apart from these new strictly epizoic diatom genera, several other new epizoic species were described in established genera living on sea turtles, such as Achnanthes elongata Majewska et Van de Vijver and A. squaliformis Majewska et Van de Vijver, observed on the carapace of olive ridley sea turtles (MAJEWSKA et al. 2017a), Labellicula lecohuiana Majewska et Van de Vijver, described from the carapace of green turtles (MAJEWSKa et al. 2017b), Olifantiella seblae Kaleli et al., found on loggerhead sea turtles (KALELI et al. 2018) in the Mediterranean Sea and several Proschkinia species (MajewsKa et al. 2019).
Recently, during a survey of the epizoic diatom flora living on loggerhead sea turtles from the Adriatic Sea, a new Catenula, C. exigua Robert et al. and a Planothidium species $P$. kaetherobertianum Van de Vijver et al. were described from the turtle carapace (ROBERT et al. 2019; VAN DE VIJVER \& BosaK 2019). On the same turtle, a relatively large population of a small monoraphid taxon was observed showing some resemblance to several established achnanthoid genera but also presenting important morphological differences placing the unknown species in one of these genera less probable. When the catch-all genus Achnanthes Bory sensu lato proved to be too heterogenous, it was gradually split up starting in 1990 by Round et al. with the re-erection of Eucocconeis Cleve ex Meister and Achnanthidium Kützing. The latter, grouping the majority of freshwater achnanthoid species, was further subdivided several years later when a handful of new genera was described such as Psammothidium Bukhtiyarova et Round, Rossithidium Round et Bukhtiyarova, Karayevia Round et Bukhtiyarova, Kolbesia Round et Bukhtiyarova, Lemnicola Round et Basson and Planothidium Lange-Bertalot (BUKHTIYARova \& Round 1996; Round \& BuKHTIYARova 1996; Round 
\& BASSON 1997). The past few years, new achnanthoid genera have continuously been described, usually based on former freshwater Achnanthes or Achnanthidium species, such as Platessa Lange-Bertalot, Trifonovia Kulikvskiy et al., Gliwiczia Kulikovskiy et al. and Skabitschewskia Kuliskovskiy et Lange-Bertalot (KRAMMER \& LANGEBertalot 2004; KULIKOVSKIY et al. 2012, 2013, 2015).

Most of these genera mainly group freshwater and limnoterrestrial species with only Achnanthes and Planothidium having some marine representatives (WiTkowski et al. 2000). In the marine realm however, monoraphid diatoms also play a major role (e.g. RiauX-Gobin \& CoMpère 2008; LobBAn et al 2012; RIAUX-Gobin et al. 2010; DESROSIERS et al. 2014) with several genera been described in the past 20 years: Astartiella Witkowski et al., Pauliella Round et Basson, Pogoneis Round et Basson, Scalariella Riaux-Gobin et al. and Madinithidium Desrosiers et al. (Round \& BASSON 1997; Moser et al. 1998 ; RiAuX-GobIN et al. 2012; DesRosiERs et al. 2014). Two monoraphid genera proved to be epizoic and associated with marine mammals: Bennettella Holmes and Epipellis Holmes but both show more affinities to cocconeioid than achnanthoid genera (Holmes 1985).

In our sample scraped from a sea turtle carapace biofilm, after a detailed analysis with SEM the unknown achanthoid taxon could not be placed in any of the established genera based on all currently available literature.

Therefore, a new genus, Majewskaea gen. nov. is described to accommodate the new species. The new species Majewskaea istriaca sp. nov. is described using light (LM) and scanning electron (SEM) microscopy from the carapace of a loggerhead sea turtle and is the generitype. The morphological features of the new genus are compared with all other morphologically similar achnanthoid genera.

\section{Material ANd Methods}

On 30. May 2016 the carapace of a juvenile loggerhead turtle named Žanja-Mara $(\mathrm{CCL}=44 \mathrm{~cm}$, weight $11 \mathrm{~kg})$ was sampled by Karin Gobić Medica in the Marine Turtle Rescue Centre in Aquarium Pula (eastern Adriatic Sea, Croatia) after having spent more than 6 months in a rehabilitation tank with circulating seawater. Epibiotic non-invasive samples were collected under the necessary permits by randomly scraping ca. $20 \mathrm{~cm}^{2}$ of the carapace with a curette. The carapace fragments were preserved in $50 \mathrm{ml}$ Falcon tubes in seawater with added formaldehyde ( $4 \%$ final concentration).

Diatom samples were prepared for LM and SEM observation following the method described in VAN DER WERFF (1955). Small parts of the sample were cleaned by adding $37 \% \mathrm{H}_{2} \mathrm{O}_{2}$ and heating to $80{ }^{\circ} \mathrm{C}$ for about $1 \mathrm{~h}$ after which, the reaction was completed by addition of $\mathrm{KMnO}_{4}$. Following digestion and centrifugation (three times 10 minutes at 3700 $\times \mathrm{g}$ ), cleaned diatom material was diluted with distilled water to avoid excessive concentrations of diatom valves on the slides and subsequently mounted in Naphrax. The slides were analyzed using an Olympus BX53 light microscope equipped with Differential Interference Contrast (Nomarski) optics and the Olympus UC30 Imaging System. Samples and slides are stored at the BR-collection (Meise Botanic Garden, Belgium). For SEM analysis, a few drops of the oxidized suspensions were filtered through a $1-\mu \mathrm{m}$ Isopore ${ }^{\mathrm{TM}}$ polycarbonate membrane filter (Merck Millipore). Parts of the filter were affixed to aluminum stubs that were sputter-coated with a Gold-Palladium layer of $20 \mathrm{~nm}$ and studied on a ZEISS Ultra SEM microscope at $3 \mathrm{kV}$ (Natural History Museum London, UK).

Diatom terminology follows Ross et al. (1979) (stria/ areola structure) and Round et al. (1990) (raphe structure). The morphology of the new genus was compared with the ultrastructure of similar genera such as Planothidium, Psammothidium, Achnanthidium, Kolbesia, Karayevia, Madinithidium and Scalariella (Round et al. 1990; Round \& BUKHTIYAROva 1996; RiauX-Gobin et al. 2012; Desrosiers et al. 2014)

\section{RESULTS}

A new monoraphid genus, Majewskaea gen. nov., is formally described. Based on its morphological features and after comparison with similar genera such as Karayevia and Madinithidium, belonging to the same family Achnanthidiaceae D.G.Mann in Round et al. (1990), the new genus is likewise placed in this family (Desrosiers et al. 2014).

\section{Majewskaea gen. nov. \\ Description}

Heterovalvate, monoraphid frustules composed of a raphe-bearing valve and a rapheless valve. Frustules relatively small. Raphe valve (RV): valve face relatively flat, rarely curved. Mantle very shallow. Raphe branches straight. Central raphe endings closely positioned to each other, shortly hooked, weakly expanded. Terminal raphe fissures bent, continuing onto the valve mantle. Striae composed of one macroareola, only near the valve apices continuous from axial area to valve margin. Most of the striae interrupted by large hyaline plate dividing the macroareolae in two parts. Areolae covered externally by porous hymenes. Virgae internally thickened, clearly raised. Raphe sternum clearly raised with developed central nodule. Central raphe endings straight to weakly deflected into opposite directions. Terminal raphe endings terminating onto small helictoglossae. Sternum valve (SV): Valves weakly convex with clearly developed, thickened, linear sternum. Mantle shallow. Striae composed of macroareolae, clearly interrupted by a large hyaline plate forming one rounded areola near the axial area and one transapically elongated areola at valve margin, both covered by porous external hymenes. Distinct, raised ridge surrounding the valve face, folded inwards over the valve margin. Internally, hyaline plate dividing the macroareolae obvious. Small vestige-like raphe slits present. Raphe sternum sunken.

Girdle composed of at least two open, narrow, unperforated bands.

Typus generis: Majewskaea istriaca sp. nov. 
Etymology: the new genus is named after our dear friend and colleague, Dr Roksana Majewska (Southwest University, Potchefstroom, South Africa) in honor of her impressive scientific contributions to the study of diatom taxa associated with sea turtles.

\section{Majewskaea istriaca sp. nov. (Figs 1-51)}

LM (Figs 1-39): Frustules heterovalvate. Valves linear, linear-lanceolate to lanceolate with straight to convex margins and weakly protracted, rostrate, broadly rounded apices. Smaller valves becoming almost elliptical. Valve dimensions $(n=50)$ : length 6-15 $\mu \mathrm{m}$, width 3-4 $\mu \mathrm{m}$. SV: Sternum raised above valve plain, often discernible in LM (Figs 8, 10, 12, 16). Striae parallel throughout almost the entire valve, becoming slight radiate towards the apices, 30-32 in $10 \mu \mathrm{m}$. RV: raphe sternum clearly developed, linear running distinctly from apex to apex. Raphe branches not or very weakly (Figs 22, 25, 29: discernible in LM. Axial area very narrow. Central area often rather distinctly but irregularly thickened. Striae nor areolae visible in LM.

SEM (Figs 40-51): Girdle not well studied due to lack of observations, even of untreated material. Girdle bands open, narrow, thin, unperforated (Figs 40, 41). Fig. 44 showing open nature of girdle bands. SV (Figs 40-47): Mantle very shallow. Internally sternum depressed, linear (Figs 41, 42). Very short, vestige-like raphe slits visible near apices (Figs 41, 42, 44, arrow). Striae interrupted by continuous hyaline plate subdividing the areolae usually in two parts (Figs 41, 42). Axial sternum bordered by continuous series of large rounded, areolae, part of larger macroareolae (Fig. 42). Near valve edge transapically elongated parts of macroareolae present. Occasionally, third areola visible near valve margin (Fig. 42). Externally, well-developed ridge surrounding the entire valve, larger near valve center. Ridge clearly folded inwards, partly covering the marginal areolae of the striae (Figs 43, 46, 47). Sternum thick, raised, linear to lanceolate (Figs 40, 43). Virgae raised extending from the sternum towards the valve margins (Figs 40, 43, 47). Striae depressed between virgae (Figs 43, 45). Areolae clearly covered by perforated hymenes (Fig. 45, arrows). Vestigial raphe slits often visible at apices (Fig. 46, arrow). RV (Figs 48-52): Raphe branches straight with shortly, unilaterally hooked central endings bearing only weakly expanded pores (Figs 48, 50). Terminal raphe fissures bent, continuing onto the mantle (Fig. 48). Striae composed of macroareolae, subdivided by large hyaline plate, ca. 50 in $10 \mu \mathrm{m}$. Axial area bordered by series of transapically elongated, short areolae whereas larger part of macroareolae visible near valve margin (Fig. 48). At apices, macroareolae never subdivided, composed of one continuous stria (Fig. 48). Internally, raphe sternum well developed, clearly raised. Central nodule thickened, expanding irregularly towards the valve margins, however, never reaching the margins (Fig. 49). Virgae distinctly thickened with striae sunken between them. Raphe branches terminating onto small helictoglossae at the apices (Figs 49, 51). Centrally, raphe endings occasionally deflected in opposite directions (Fig. 49), usually straight (Fig. 52). Areola coverings visible as perforated, external hymenes (Fig. 52).

Holotype: BR-4583 (Meise Botanic Garden, Belgium) Isotype: PLP-373 (University of Antwerp, Belgium), HRNDC-000437 (Croatian National Diatom Collection) Type locality: Loggerhead turtle, Pula, Croatia, Adriatic Sea, sample 13 Žanja-Mara carapax, (leg. K. GobIć MedicA, 30/05/2016)

Etymology: The specific epithet 'istriaca' refers to the Istrian peninsula where the loggerhead turtle was found.

Ecology: Majewskaea istriaca was so far only found on the carapace of a loggerhead turtle. The associated diatom flora was very diverse and species-rich and composed of Catenula exigua Robert et al., an unknown Bifibulatia Takano species and several Nitzschia Hassall, Fallacia A.J.Stickle et D.G.Mann, Parlibellus E.J.Cox and Amphora Ehrenberg ex Kützing species.

\section{Discussion}

The genus Majewskaea possesses a unique combination of morphological features that has never been observed in any other monoraphid genus. The frustules are clearly heterovalvate and thus only a few genera come into question as host genus for the unknown species in this paper. The structure of the striae, composed of one large macroareola subdivided by a hyaline plate, is entirely different from the striae in genera such as Achnanthes, Achnanthidium, Psammothidium, Rossithidium, Lemnicola, Platessa, Planothidium, Gliwiczia and Skabitschewkia (Round et al. 1990; Round \& BukHTIAYRova 1996; Round \& BASSON 1997; KULIKOVSKIY et al. 2013, 2015) that are composed of uni- to multiseriate series of small, rounded areolae. A similar stria structure composed of macroareolae, on the other hand, is observed in the genera Scalariella, Madinithidium, Kolbesia and Karayevia (BukHtiYarova 1999; RiauX-Gobin et al. 2012; DesRosiers et al. 2014). Therefore, the new genus Majewskaea is compared in detail with these four genera.

Two of the similar genera, Karayevia and Kolbesia, however, have a rather complicated taxonomic history. Both genera were described and separated in 1996 by ROUND \& BUKHTIYAROva based, however, on unclear morphological characters. Both genera were declared invalid as a formal indication of the generitypes was missing. This was rectified in 1998 by Round who unfortunately made the mistake to indicate twice the name $A$. cleve $i$ for both Karayevia (correct) and Kolbesia (incorrect). The latter was considered later a lapsus for A. kolbei and the genus was considered valid. BukHtIYARova (1999) transferred a year later the generitype of Kolbesia, $K$. kolbei (Hustedt) Round et Bukhtiyarova together with 


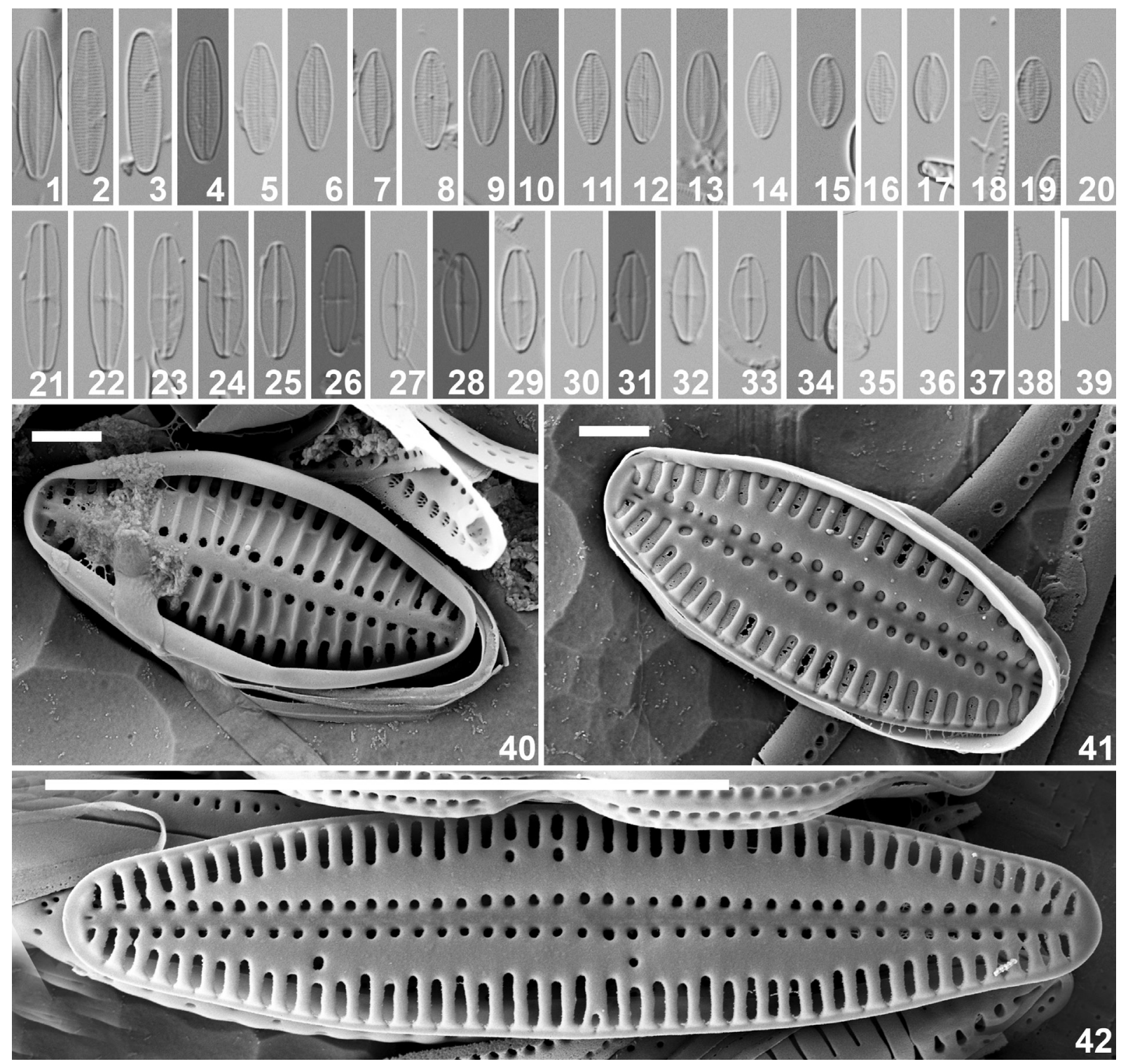

Figs 1-42. Majewskaea istriaca sp. nov. LM and SEM pictures taken from the holotype population (loggerhead "Žanja-Mara" carapace sample), Adriatic Sea, Croatia: (1-39) Light microscopy observations showing size diminution series and the variability of the sternum valve outline (1-20) and raphe valve outline (21-39); (40) SEM external view of an entire sternum valve showing the typical recurved marginal crest, the split macroareolae and several girdle bands; (41) SEM internal view of an entire sternum valve showing the split macroareolae, the depressed sternum and several girdle bands; (41) SEM internal view of an entire sternum valve showing the split macroareolae, the depressed sternum and the vestigial raphe slits. Scale bar $10 \mu \mathrm{m}(1-39,42), 1 \mu \mathrm{m}(40,41)$.

several other taxa into the genus Karayevia indicating that way the superfluous character of the genus Kolbesia. In 2006, the genus description of Karayevia was emended including the macroareola structure in the genus description. An extra term, postmacroareola, was likewise introduced for striae composed of several macroareolae (RIAUX-GobIN et al. 2012). RiAUX-GobIN et al. (2012) reported that the genus Karayevia is highly heterogeneous based on several features such as the presence/absence of areolae on the SV mantle and the highly variable stria structure within the emended genus. WiTKOWSKI et al. (2016) contested subsequently the inclusion of Kolbesia in Karayevia when they described a new Kolbesia species, K. sinica Krzywda et al. based on morphological and molecular data. According to them, the genus Karayevia consists of species having striae composed of small, rounded areolae such as K. clevei, whereas Kolbesia possesses striae composed of (post) macroareolae covered externally. This subtle difference had been included in the original genus descriptions (Karayevia: 'areolae circular' vs. Kolbesia: 'areolae elongate and separated, few in each stria', see Round \& BUKTIYAROVA 1996, pp. 353-354). Molecular research including species with different stria/areola types will be necessary to clarify this issue. In the present paper, only these Karayevia/Kolbesia species with (post)macroareolae are used for the morphological comparison. The new genus differs from Karayevia/Kolbesia by the presence of the large external ridge folding over part of the valve face (absent in Karayevia/Kolbesia), the 

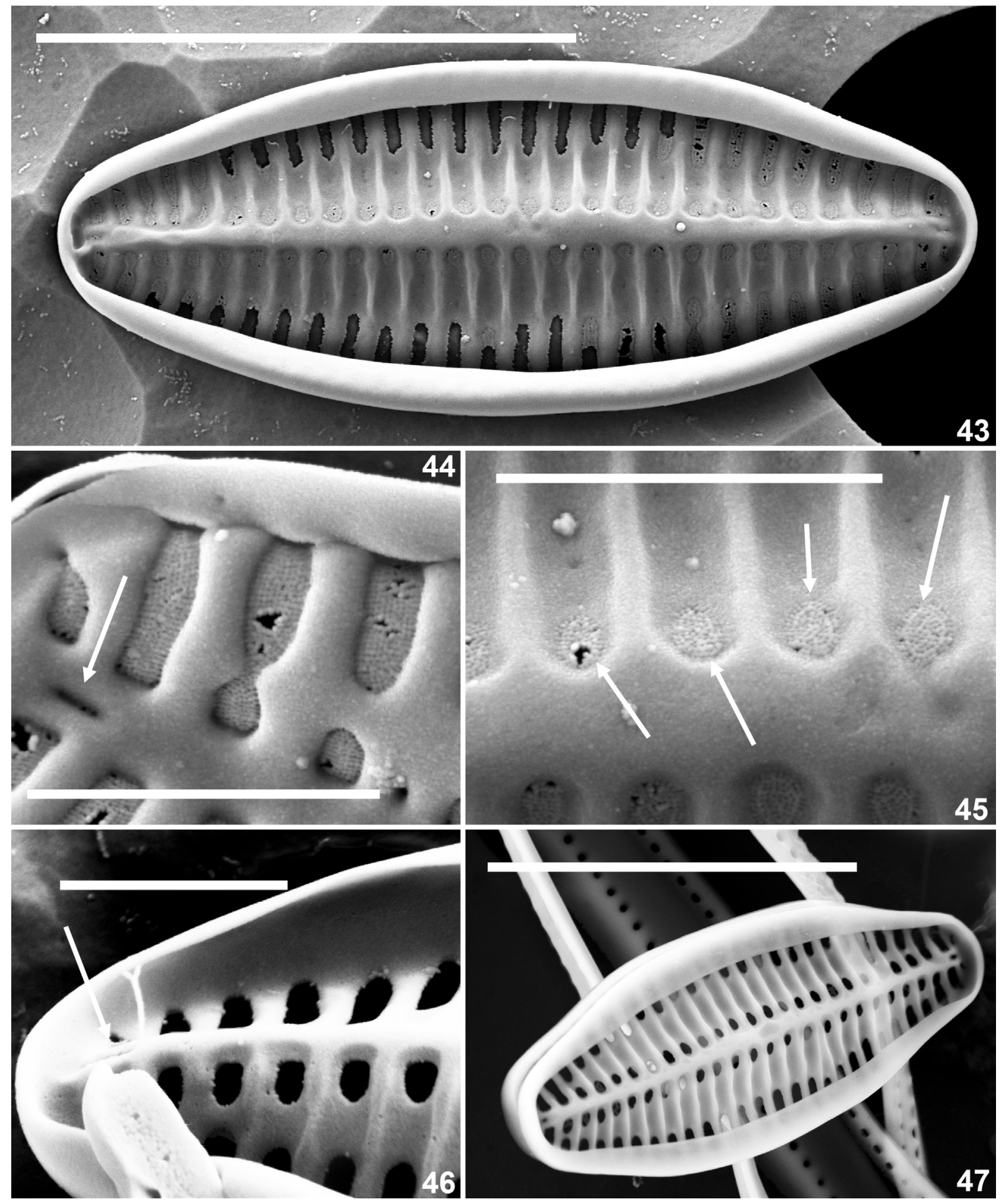

Figs 43-47. Majewskaea istriaca sp. nov. SEM pictures taken from the holotype population (loggerhead "Žanja-Mara" carapace sample), Adriatic Sea, Croatia: (43) SEM external view of an entire sternum valve showing the typical recurved marginal crest and the split macroareolae. The areolae near the axial area are filled by their hymenes. (44) SEM external detail of the valve apex with the vestigial raphe slit (arrow); (45) SEM external detail of the areolae near the sternum, filled with porous hymenes (see arrows); (46) SEM external detail of the valve apex with the vestigial raphe slit (arrow); (47) SEM external view of an entire sternum valve showing the typical recurved marginal crest. Scale bar $10 \mu \mathrm{m}(43,47), 1 \mu \mathrm{m}(44-46)$.

distinct presence of vestigial raphe slits in SV, the presence of the large hyaline plate, subdividing the striae in two postmacroareolae (absent in Karayevia/Kolbesia), the longitudinal ridges forming the raphe sternum in the valve interior (never observed in any Karayevia/Kolbesia species) and the perforated hymenes closing the areolae halfway in the areolar canal (contrary to the internal closings in Karayevia/Kolbesia). Several Karayevia/Kolbesia taxa such as Karayevia laterostrata or K. nitidiformis possess striae composed of two large areolae with the 


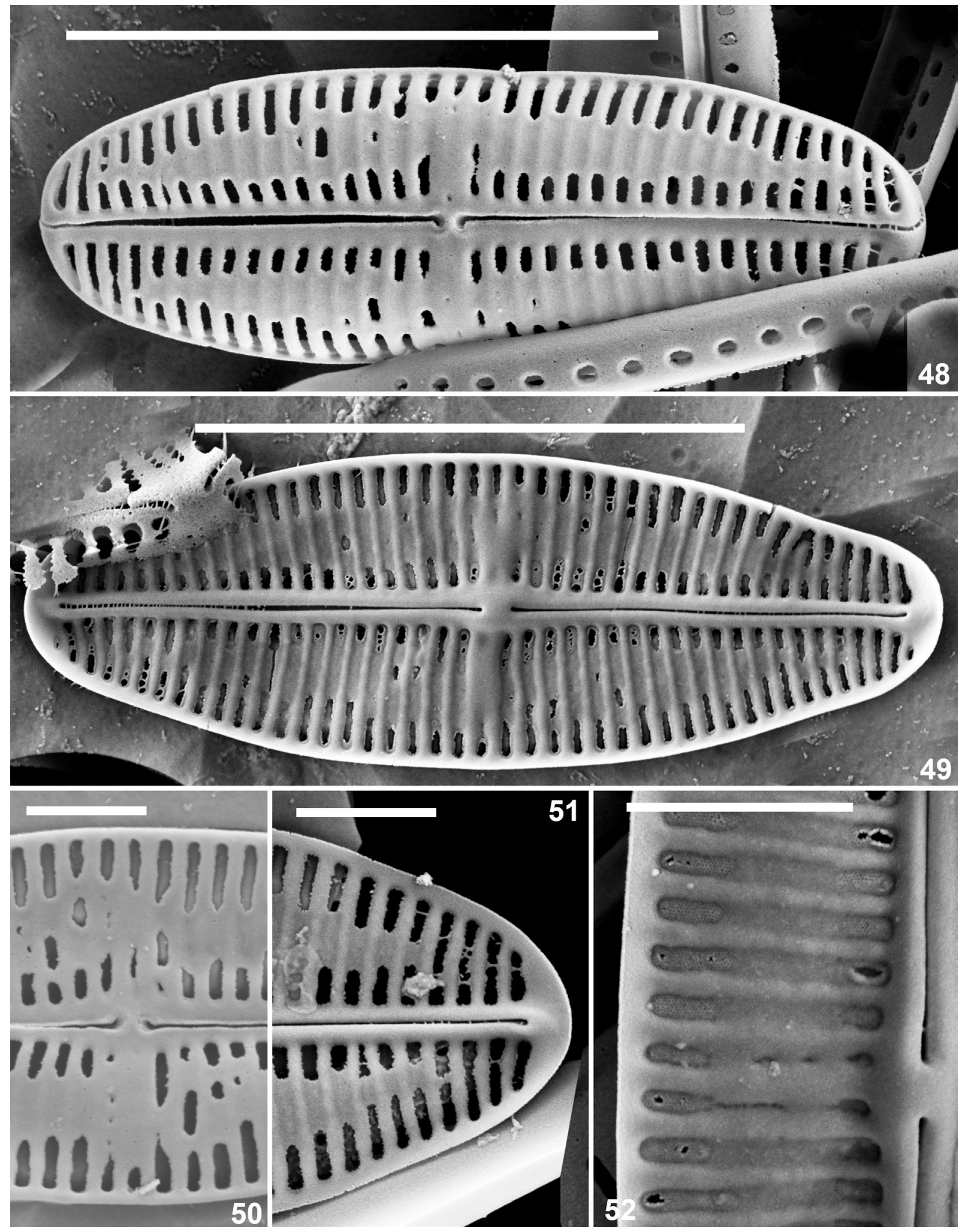

Figs 48-52. Majewskaea istriaca sp. nov. SEM pictures taken from the holotype population (loggerhead "Žanja-Mara" carapace sample), Adriatic Sea, Croatia: (48) SEM external view of an entire raphe valve showing the course of the raphe, the bent terminal raphe fissures, the split macroareolae and the slightly enlarged central raphe endings; (49) SEM internal view of an entire raphe valve showing the raphe branches, the weakly enlarged central nodule, the very small helictoglossae and the raised virgae; (50) SEM external detail of the central raphe endings and the asymmetrical central area; (51) SEM internal detail of the valve apex with the helictoglossa; (52) SEM internal detail of closed macroareolae. Scale bar $10 \mu \mathrm{m}(48,49), 1 \mu \mathrm{m}(50-52)$. 
areolae bordering the axial area always being the largest and a second, much smaller areola at the valve margin. The presence of vestigial raphe slits on the SV valve has been reported in the genus Psammothidium where species such as $P$. incognitum or $P$. confusum present similar slits (Le COHU \& MAILlaRd 1983). However, later analysis showed that these slits were covered on the inside by perforated hymenes structurally similar to the hymenes covering the areolae (VAN DE VIJVER, pers. obs.), contrary to the slits in Majewskaea where the slits were never covered internally nor externally by perforated hymenes. The recently described Kolbesia sinica shows some resemblance to the genus Majewskaea. However, this Kolbesia species never possesses the typical hyaline plate subdividing the striae, the areolae seem to be closed internally by hymenes (and not halfway the areolar canal), the typical marginal crest folding over the valve face is absent and the terminal raphe fissures are hooked on the valve face and do not seem to continue onto the mantle. Vestigial raphe slits were never observed. Conspecificity between $K$. sinica and Majewskaea has to be excluded therefore.

Two other genera show the typical macroareolae: Madinithidium and Scalariella. The genus Scalariella, described from the sub-Antarctic Kerguelen Islands (RIAUX-GobIN et al. 2012) shows one macroareola on the SV whereas the RV is characterized by two postmacroareolae, separated by a hyaline, lunate-shaped plate. A subdivision of the macroareolea on the SV, as is the case in Majewskaea was never observed in any of the Scalariella species (RIAUX-GobIN et al. 2012, figs 1, 2, $5)$. The areolae are closed by non-perforated hymenes (RIAUX-GobIN et al. 2012, p.15: "areolae occluded by thin, uniform hymen without visible slits") contrary to the genus Majewskaea where the hymenes are clearly perforated. The internal structure of the striae, forming one large open groove bordered by well-developed virgae as is seen in Majewskaea was never observed in Scalariella where the hyaline plate subdividing the striae is clearly raised separating both postmacroareolae (see for instance RIAUX-GoBIN et al. 2012, figs 15-16). The external raphe branches in Scalariella are clearly curved (despite the text stating that the raphe is "filiform and straight" (RIAUX-GoBIN et al. 2012, p. 15). terminating in hooked terminal raphe fissures. It is however unclear from the illustrations in RIAUX-GobIN et al. (2012, figs $12,14,17)$ whether the raphe fissures continue onto the mantle or terminate at the valve margin. In Majewskaea, the terminal raphe fissures continue onto the valve mantle (see Fig. 48). RiAUX-Gobin et al. (2012) also mention the presence of "two lateral sunken recesses in the hymenes of the marginal areolae", a feature never observed in Majewskaea. On the other hand, the typical marginal ridge bordering the entire SV in Majewskaea, was never observed in Scalariella. Therefore, given these morphological differences, placing the new monoraphid taxon within the genus Scalariella is not the most ideal situation.
Finally, the genus Madinithidium was recently described by DeSRosiERs et al. (2014) based on a small monoraphid diatom found in Martinique. Madinithidium is characterized by the presence of wide, distinctly depressed macroareolae on both SV and RV occluded internally by perforated hymenes, a clearly raised raphesternum, both externally and internally, terminal raphe fissures that are doubly hooked, the absence of vestigial raphe slits on the SV and open, non-perforated girdle bands. The typical postmacroareolae found in Majewskaea with the large hyaline plate on both SV and RV have never been found in Madinithidium. At present, six taxa are placed in the genus, mainly small-celled monoraphid taxa found in tropical coral sands but also taxa originating from Vietnam and Turkey (RIAUX-Gobin et al. 2010; DesrosiERs et al. 2014; KULIKovskiY et al. 2019). None of these six taxa shows any of the typical features that are found in the new genus Majewskaea. The marginal ridge on the $\mathrm{SV}$ is absent on all six known Madinithidium taxa, the structure of the raised sternum on the SV, the presence of the vestigial raphe slits on the SV, the subdivision of the striae on the RV and the weakly developed stauros on the RV, are all features that at present were observed in Majewskaea but absent in Madinithidium. Therefore, the separation between Majewskaea and Madinithidium based on morphological features is justified.

Whether Majewskaea is a characteristic component of epizoic diatom community needs to be proven. At present, only one turtle hosted a large population on its carapace. The turtle was brought in the Pula Rescue Center (Croatia) and remained several months in a closed tank with seawater inflowing from the nearby sea for recovery. Unfortunately, no sampling was performed when the turtle arrived in the rescue center and the investigated samples were only taken after several months. Analyses of the diatom flora on the carapace of other Adriatic turtles revealed a different epibiont diatom community (unpublished data). The flora on Žanja-Mara proved to be composed of other unique taxa such as Catenula exigua, Planothidium kaetherobertianum and an unknown Bifibulatia species, all taxa never observed on other Adriatic turtles (ROBERT et al. 2019; VAN DE VIJVER \& BOSAK 2019). However, the diatom survey of the Adriatic turtle flora only recently started and only a limited number of turtle samples has been analysed so far making undersampling and underreporting likely causes for the lack of distribution data of Majewskaea. Surveys of the benthic diatom flora in the Mediterranean Sea of the Black Sea such as Álvarez-Blanco \& Blanco (2014) or KALELI et al. (2017) did not mention nor illustrate valves that could be attributed to Majewskaea. Further research on the Adriatic turtle diatom flora in combination with an analysis of the benthic flora in the Adriatic Sea will be necessary to determine the correct distribution of Majewskaea.

At present it is unclear if other, previously described species should be transferred to the new genus. Hendey (1977) described Navicula incongruens Hendey 
from the coast of Cornwall, UK. Only one valve bearing a raphe is illustrated (HENDEY 1977, fig. 10). The drawing shows an elliptic-lanceolate valve with a clear hyaline interruption in the striae, consistent with what was observed in Majewskaea. Conspecificity has to be excluded based on the much higher stria density in $M$. istriaca (50 vs 14 in $10 \mu \mathrm{m}$ ). Unfortunately, HENDEY (1977) never showed a second valve so we have no idea whether the species should actually be regarded as a monoraphid species rather than a biraphid naviculoid. Analysis of the type material will be necessary to clarify this problem.

Other taxa that might be placed within the genus Majewskaea include several unidentified achnanthoid that were currently successfully cultured from Florida. Their molecular phylogeny shows a relation with the clades of Schizostauron, Astartiella and Madinithidium (WITKOWSKI, pers. comm.). Finally several unpublished valves from the Mozambique Channel coral sand could also belong to Majewskaea (WITKOWSKI, unpubl. res.). Further research will be necessary however to determine their exact taxonomic position.

\section{ACKNOWLEDGEMENTS}

The authors thank to Karin Gobić Medica and Dr Milena Mičić from Aquarium Pula, Croatia for their invaluable help during the material collection. Dr Catherine Riaux-Gobin is thanked for stimulating discussions about the new taxon. Mrs Myriam de Haan is acknowledged for her help with the SEM analysis. This work has been supported in part by the Croatian Science Foundation under the project UIP-2017-05-5635 (TurtleBIOME).

\section{REFERENCES}

Álvarez-Blanco, I. \& Blanco, S. (2014): Benthic diatoms from Mediterranean coasts. - Bibliotheca Diatomologica 60: $1-409$.

BukhtiYarova, L. \& Round, F.E. (1996): Revision of the genus Achnanthes sensu lato section Marginulatae Bukh. sect. nov. of Achnanthidium Kütz. - Diatom Research 11: 1-30.

BukhtiYarova, L. (1999): Diatoms of Ukraine. Inland waters. pp. 1-133, National Academy of Sciences of Ukranine. M.G. Kholodny Institute of Botany, Kyiv, Ukranie.

Bukhtiyarova, L. (2006): Additional data on the diatom genus Karayevia and a proposal to reject the genus Kolbesia. - Beihefte zur Nova Hedwigia 130: 85-96.

Desrosiers, C.; Witkowski, A.; RiauX-Gobin, C.; Zglobicka, I.; Kurzydlowski, K.J.; Eulin, A.; Leflaive, J. \& Ten-Hage, L. (2014): Madinithidium gen. nov. (Bacillariophyceae), a new monoraphid diatom genus from the tropical marine coastal zone. - Phycologia 53: 583-592

Frankovich, T.A; Ashworth, M.P.; Sullivan, M.J.; Veselá, J. \& STACY, N.I. (2016): Medlinella amphoroidea gen. et sp. nov. (Bacillariophyta) from the neck skin of Loggerhead sea turtles (Caretta caretta). - Phytotaxa 272: 101-114

Hendey, N.I. (1977): The species diversity index of some in-shore diatom communities and its use in assessing the degree of pollution on parts of the North Coast of Cornwall. - Beihefte zur Nova Hedwigia 54: 355-378.
Holmes, R.W. (1985): The morphology of diatoms epizoic on cetaceans and their transfer from Cocconeis to two new genera, Bennettella and Epipellis. - British Phycological Journal 20: 43-57

Kaleli, A.; KulikovskiY, M. \& Solak, C.N. (2017): Some New Records for Marine Diatom Flora of Turkey From Akliman, Sinop (Black Sea). - Turkish Journal of Fisheries and Aquatic Sciences 17: 1387-1395.

Kaleli, A.; Krzywda, M.; WitKowski, A.; RiauX-Gobin, C.; SOLAK, C.N.; ZGlobicka, I.; PloCinsKI, T.; GRZONKA, J.; Kurzydlowski, K.J.; Car, A.; Desrosiers, C.; Kaska, Y. \& MCCARTNEY, K. (2018): A new sediment dwelling and epizoic species of Olifantiella (Bacillariophyceae), with an account on the genus ultrastructure based on Focused Ion Beam nanocuts. - Fottea 18: 216-226.

Krammer, K. \& LANGe-Bertalot, H. (2004): Bacillariophyceae 4. Teil: Achnanthaceae, Kritische Erganzungen zu Navicula (Lineolatae), Gomphonema. Gesamtliteraturverzeichnis Teil 1-4 [second revised edition] [With „Ergänzungen und Revisionen" by H. Lange Bertalot]. - In: EтTL, H.; Gerloff, J.; Heynig, H. \& Mollenhauer, D. (eds): Süßwasserflora von Mitteleuropa. Vol. 2. - pp. 1-468. Spektrum Akademischer Verlag, Heidelberg.

Kulikovskiy, M.S.; Lange-Bertalot, H.; Metzeltin, D. \& WitKowsKi, A. (2012): Lake Baikal: Hotspot of endemic diatoms I. - Iconographia Diatomologica 23: 1-607.

Kulikovskiy, M.; Lange-Bertalot, H. \& Witkowski, A. (2013): Gliwiczia gen. nov. a new monoraphid diatom genus from Lake Baikal with a description of four species new for science. - Phytotaxa 109: 1-16

Kulikovskiy, M.S.; Lange-Bertalot, H. \& KuZnetsova, I.V. (2015): Lake Baikal: hotspot of endemic diatoms II. - Iconographia Diatomologica 26: 1-656.

Kulikovskiy, M.; Maltsev, Y.; Andreeva, S.; Glushchenko, A.; Gusev, E.; Podunay, Y.; Ludwig, T.V.; Tusset, E. \& KocioleK, J.P. (2019): Description of a new diatom genus Dorofeyukea gen. nov. with remarks on phylogeny of the family Stauroneidaceae. - Journal of Phycology 55: 173-185.

KützING, F.T. (1844): Die Kieselschaligen Bacillarien oder Diatomeen. - $152 \mathrm{pp}$, pls 1-30, Nordhausen.

Le Cohu, R. \& MaILlard, R. (1983): Les diatomées monoraphidees des îles Kerguelen. - Annales de Limnologie 19: $143-167$

Majewska, R.; Kockiolek, J.P.; Thomas, E.W.; De Stefano, M.; Santoro, M.; Bolaños, F. \& Van De ViJver, B. (2015): Chelonicola and Poulinea, two new gomphonemoid diatom genera (Bacillariophyta) living on marine turtles from Costa Rica. - Phytotaxa 233: 236-250.

Majewska, R.; De Stefano, M.; Ector, L.; Balaños, F.; Frankovich, T.A.; Sullivan, M.J.; Ashworth, M.P. \& VAN DE VIJVER, B. (2017a): Two new epizoic Achnanthes species (Bacillariophyta) living on marine turtles from Costa Rica. - Botanica Marina 60: 303-318.

Majewska, R.; De Stefano, M. \& VAn De ViJver, B. (2017b): Labellicula lecohuiana, a new epizoic diatom species living on green turtles in Costa Rica. - Beihefte zur Nova Hedwigia 146: 23-31.

Majewska, R.; Bosak, S.; Frankovich, T.; Ashworth, M.; Sullivan, M.; Robinson, N.; Lazo-Wasem, E.; Pinou, T.; Nel, R.; Manning, S. \& VAN DE ViJver, B. (2019) Six new epibiotic Proschkinia (Bacillariophyta) species and new insights into the genus phylogeny. - European Journal of Phycology 54: 609-631.

Meister, F. (1912): Die Kieselalgen der Schweiz. Beitrage 
zur Kryptogamenflora der Schweiz. Matériaux pour la flore cryptogamique suisse. Vol. IV, fasc. 1.. pp. 1-254, pls I-XLVIII. Bern: K.J. Wyss.

Moser, G.; Lange-Bertalot, H. \& Metzeltin, D. (1998): Insel der Endemiten Geobotanisches Phänomen Neukaledonien (Island of endemics New Caledonia - a geobotanical phenomenon). - Bibliotheca Diatomologica 38: 1-464.

Riaux-Gobin, C.; Witkowski, A. \& Compère, P. (2010): SEM survey and taxonomic position of small-sized Achnanthidium (Bacillariophyceae) from coral sands off Réunion Island (Western Indian Ocean). - Vie et Milieu 60: 157-172.

RiauX-Gobin, C.; Witkowski, A. \& Ruppel, M. (2012): Scalariella a new genus of monoraphid diatom (Bacillariophyta) with a bipolar distribution. - Fottea 12: $13-25$.

Robert, K.; Bosak, S. \& VAn de ViJver, B. (2019): Catenula exigua sp. nov., a new marine diatom (Bacillariophyta) species from the Adriatic Sea. - Phytotaxa 414: 113-118.

Ross, R.; Cox, E.J.; Karayeva, N.I.; ManN, D.G.; Paddock, T.B.B.; SimOnSEN, R. \& Sims, P.A. (1979): An amended terminology for the siliceous components of the diatom cell. - Beihefte zur Nova Hedwigia 64: 513-533.

Round, F.E.; Crawford, R.M. \& Mann, D.G. (1990): The diatoms: Biology and Morphology of the genera. - 747 pp, Cambridge University Press, Cambridge.

Round, F.E. \& BukhtiYarova, L. (1996): Four new genera based on Achnanthes (Achnanthidium) together with a re-definition of Achnanthidium. - Diatom Research 11: 345-361.

Round, F.E. \& BASSON, P.W. (1997). A new monoraphid diatom genus (Pogoneis) from Bahrain and the transfer of previously described species $A$. hungarica and $A$. taeniata to new genera. - Diatom Research 12: 71-81.

VAN de ViJver, B. \& BosaK, S. (2019): Planothidium kaetherobertianum, a new marine diatom (Bacillariophyta) species from the Adriatic Sea. - Phytotaxa 425: 105-112.

VAN DER WERFF, A. (1955): A new method of concentrating and cleaning diatoms and other organisms. - Verhandlungen der Internationalen Vereinigung für Theoretische und Angewandte Limnologie 12: 276-277.

Witkowski, A.; Lange-Bertalot, H. \& Metzeltin, D. (2000): Diatom Flora of Marine Coasts I. - Iconographia Diatomologica 7: 1-925.

Witkowski, A.; Li, Ch.; Zglobicka, I.; Yu, S.-X.; Ashworth, M.; DABEK, P.; QIN, S.; TANG, CH.; KRZYWDA, M.; Ruppel, M.; Theriot, E.C.; JANSEN, R.K.; CAR, A.; Plozinski, T.; Wang, Y.-Ch.; SABIR, J.S.M.; DaniszewsKa-KowalcZYK, G.; KIERZEK, A. \& HAJRAH, N.H. (2016): Multigene assessment of biodiversity of diatom (Bacillariophyceae) assemblages from the littoral zone of the Bohai and Yellow Seas in Yantai Region of northeast China with some remarks on ubiquitous taxa. - Journal of Coastal Research 74 (Special issue): 166-195.

(C) Czech Phycological Society (2020)

Received December 19, 2019

Accepted April 6, 2020 